\title{
The global financial crisis and rural-urban migration
}

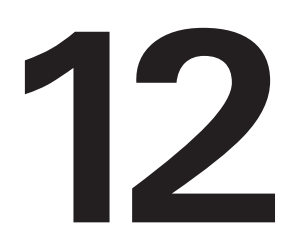

\section{Sherry Tao Kong, Xin Meng and}

\author{
Dandan Zhang
}

\section{Introduction}

Since the second half of 2008, the global financial crisis (GFC) reduced export orders sharply and led to a decline in China's economic growth. As China's exporting industries are labour intensive and most likely to employ rural migrants, it is widely believed that the global financial crisis has had significant negative impacts on the employment and/or wages of rural migrants. At the height of the crisis, laid-off Chinese migrant workers protested outside closed factories and millions lamented lost jobs and embarked on journeys home much earlier than the usual Chinese New Year visit. Many were apprehensive, worrying that the worst was yet to come. At that time, policymakers and academics alike were convinced there would be a significant, adverse labour-market adjustment for rural migrants (Chen 2009; NBS 2009; Kong et al. 2009). In last year's China Update volume, we estimated that the total employment impact of the global financial crisis was between 13 and 19 per cent. We also emphasised, however, that the adverse shock to employment was in fact the joint outcome of the global financial crisis and China's domestic policy stance - most prominently, the contractionary macroeconomic policy and the implementation of the New Labour Contract Law (Kong et al. 2009).

With the fiscal and monetary expansions in response to the global financial crisis and the gradual recovery of external demand, China bounced back forcefully from a gross domestic product (GDP) growth rate of 6.1 per cent in the year to the first quarter to 7.8 per cent to the second quarter of 2009. By the end of 2009 , the growth rate exceeded the 8 per cent target. Now that the immediate crisis is over, it is time to evaluate how much the global financial crisis has affected migrant labour-market outcomes and whether these effects were short lived or long lasting.

Using the panel surveys of rural-urban migrants and rural households in the Rural-Urban Migration in China and Indonesia (RUMiCI) Project, this chapter 
compares the labour-market outcomes of migrants in cities in 2008 and 2009. Much to our surprise, we observe small employment effects and virtually no reduction in working hours or wages for migrants. We try to understand the logic behind our findings. We find that the real adverse effect of the global financial crisis is felt mainly by the rural sector-to where the unemployed migrant workers from cities returned - and the multiplier effect of the reduction in income of unemployed migrant workers, which suppressed demand in the rural sector, which, in turn, further suppressed rural off-farm jobs. This multiplier effect is very large and has not received attention in the literature before.

The chapter is structured as follows. The next section reviews the literature and hypothesises about the types of labour-market adjustment we might expect to observe. This is followed by a discussion of the data and an examination of labour-market adjustments from the urban and rural labour-market perspectives. The final section concludes the chapter.

\section{Earlier findings and our hypothesis}

There have been two important studies of the impact of the global financial crisis on rural-urban migrants: Kong et al. (2009) and Huang et al. (2010). Using a representative sample of 1200 households in six provinces in rural China, Huang et al. (2010) find that the initial negative impact of the crisis on rural migrants' employment has been significant. They estimate that between September 2008 and April 2009, 17 per cent (up to 45 million) of rural dwellers with off-farm employment either lost their jobs or delayed their move out of the agricultural sector. Farmers, however, adapted to the crisis more quickly than expected. By April 2009, 25 million of those rural workers who initially lost their off-farm jobs had found new positions and by August this number had increased to 32 million. To explain this phenomenon, Huang et al. (2010) suggest that the quick recovery was a result of the improved flexibility of China's labour market and rural workers' willingness to accept lower wages. They estimate that the average monthly earnings of the employed off-farm workers fell by 2.4 per cent-from RMB1086 in 2008 to RMB1062 in January-April 2009.

Two other reports from the Ministry of Human Resources and Social Security of China (MoHRSS) show an even more optimistic picture. A report entitled 'The response of China's employment of rural migrants to the GFC' (MoHRSS 2009) shows that, between the end of 2008 and April 2009, 70 million rural migrants moved from the city back to their home villages, including 20 million rural migrants who lost their jobs in cities due to the global financial crisis. Among the 70 million returning migrants, 95 per cent obtained new employment in 
cities. The unemployment rate for rural migrants in Chinese cities was less than 3 per cent. The total number of rural migrant workers in cities in fact increased from 140 million in 2008 to 150 million in 2009.

The other report (MoHRSS 2010) focuses on the employment situation of migrants in 2009 and is based on a survey conducted in 90 counties throughout 27 provinces in early 2010. The survey interviewed 9081 rural migrants and collected information including their employment situation, wage remuneration, willingness to work in cities and employment expectations. The survey data showed that the average monthly earnings of rural migrants increased by 12.9 per cent from 2008 to 2009, with 6.7 and 11.5 per cent increases for wage/salary earners and the self-employed, respectively.

These studies revealed that for rural migrants, who bore most of the initial brunt of the economic downturn, their employment levels had essentially recovered from the crisis by late 2009. These studies provide conflicting evidence, however, on changes in earnings. In addition, all the above studies are based on surveys conducted at the sending (or migrant-source) areas and on retrospective data, which might not accurately reflectwhat happened to rural migrants in their destination cities. In this chapter, we use consistent surveys of rural households as well as city migrants to re-examine this issue and to paint a more complete picture of the effect of the global financial crisis.

In a modern labour market, a negative economic shock will generate unemployment or depressed wages in the market in which the shock occurs. In a developing economy, however, a demand shock to the 'modern sector' labour market might not be directly detected in that market because of the dual labourmarket structure of the economy. With a dual economic structure, the 'traditional sector' provides a 'fallback' position for most migrant workers. Whenever the wages in the modern sector fall below the reservation wage, workers will move back to the 'traditional sector' provided that the cost of moving is not too high (Lewis 1954; Ranis and Fei 1961). This process happened during the East Asian financial crisis in Indonesia, where millions of workers moved back to the agricultural sector and very little unemployment was detected in the modern sector (Hugo 2000; Manning 2000; Fallon and Lucas 2002).

This relationship between the modern and traditional sectors is even stronger in China for the following reasons. First, migrants often come to cities alone due to the restrictions on welfare access in cities for families and children. Consequently, the cost of returning to rural areas is relatively low. Second, migrants normally do not have unemployment insurance and do not have health or pension insurance in cities. Without a job, it is very hard for them to survive in cities, whereas the agricultural sector provides a subsistence level of welfare (housing and food). The migrants might see this difference between the two 
sectors either as a lower effective urban sector wage or a higher reservation wage set in the traditional sector. The end result is to increase the probability of making a return migration decision. In effect, the only way that migrants can cushion the adverse effects of economic shocks that affect their employment or earnings is to return to rural areas and seek alternative employment.

Considering this special institutional setting of rural-urban migration in China, the effect of any economic shock on migrant labour-market outcomes should be examined from two directions. First, when economic shocks come, many affected migrant workers move back to rural hometowns where they find offfarm jobs or become underemployed farmers, which, in turn, could suppress agricultural productivity. Second, for those affected migrants who are unwilling to move back to their rural hometowns, we could observe an increase in open unemployment, shifting to informal employment or a reduction in wage rates.

Thus, to provide a more complete picture of the effect of the global financial crisis on migrant workers, we examine urban and rural labour markets using survey data for sending rural regions and receiving urban cities from the RUMiCI surveys of 2008 and 2009. Given the 'buffer' role that the rural sector plays, we expect that most of the impact of the global financial crisis is felt by the rural sector.

\section{Data}

The RUMiCI survey started in 2008. The sampling strategy and survey instruments can be found on the Internet (<http://rumici.anu.edu.au $>$ ). The uniqueness of the survey in China is that it surveys three groups of households: 5000 rural-urban migrant households who worked in 15 designated cities (migrant survey); 5000 urban households in the same cities ${ }^{1}$ (urban survey); and 8000 rural households from nine provinces where the 15 cities are located (rural survey). RUMiCI was designed to be a panel survey and the second wave was conducted in 2009.

Due to the high mobility of rural migrants (especially during the economic downturn), the attrition rate for the migrant sample is extremely high (about 60 per cent). Thus, in 2009, in addition to the 40 per cent of tracked households, a group of new households was randomly selected based on the same sampling frame and added into the second wave of the survey. As a result, the urban migrant sample in 2009 contains 40 per cent of the households sampled in 2008

\footnotetext{
1 The urban survey covers all 15 cities included in the migrant survey plus four additional cities. Thus, we have a total of 19 cities for the urban survey.
} 
that were successfully tracked in 2009 (that is, the panel) and 60 per cent of households newly sampled in 2009. In contrast, the attrition rates for rural and urban resident households are much lower (below 10 per cent).

We believe the impact of the global financial crisis was concentrated from the second half of 2008 to the first half of 2009. The two waves of RUMiCI data cover the period before and during this period. The migrant survey in 2008 started in March and ended in June. About 93 per cent of interviews were finished by the end of May. The survey in 2009 was conducted over six months starting from March and ending in August, with 73 per cent of households interviewed by the end of May (see Appendix Table 12.A1 for a distribution of survey times in the two years). The rural household survey was conducted between March and May 2008 and April and June 2009. Thus, we use the 2008 data to indicate the pre-global financial crisis situation while using 2009 data to indicate the global financial crisis period. A comparison between the two survey years will enable us to identify changes in migrant labour-market outcomes before and during the crisis.

Here we focus on individuals who are aged sixteen to sixty-five and are in the labour market. ${ }^{2}$ The total number of observations in our migrant sample is 7153 and 7567 for the first and second waves, respectively. The number of observations for the rural sample is 20451 and 20408 for the two waves, respectively. Note that in the rural survey, all household members are reported in the survey, including those who were not present at the time of the survey. For individuals who were not present at the time of the survey, other household members who were present reported their information. In most cases, the respondent was the household head. We are therefore able to examine the difference in characteristics between current migrants and non-migrants from the rural survey. The data for migrants could suffer, however, from larger measurement errors. Due to this inaccuracy, it is important to complement the information on migrant workers from their rural origin with information collected from the migrants themselves in the cities. Table 12.1 presents the summary statistics of the basic demographic characteristics of the two samples for both waves.

On average, the migrant sample is 31.3 years of age in 2008 and increased by about one year to 32.2 in 2009 . About 58 per cent are males, and the proportions who are married or cohabitate are 63 and 66 per cent for the two years, respectively. The average years of schooling are about nine years and slightly higher $(0.17$ years) for the 2009 sample. This increase seems to come from the slightly higher proportion of senior high school graduates in the sample for 2009.

2 An individual is defined to be in the labour force if he/she is between sixteen and sixty-five years of age and is stated to be currently working (including re-employed retired people), an unpaid family worker, unemployed or waiting to be assigned to a job. This definition applies to migrant and rural samples. 
China: The Next Twenty Years of Reform and Development

Table 12.1 Summary statistics for migrant and rural samples

\begin{tabular}{|c|c|c|c|c|c|c|c|c|}
\hline & \multirow{2}{*}{\multicolumn{2}{|c|}{ Migrant sample }} & \multicolumn{6}{|c|}{ Rural sample } \\
\hline & & & \multicolumn{2}{|c|}{$\begin{array}{c}\text { Total } \\
\text { sample }\end{array}$} & \multicolumn{2}{|c|}{$\begin{array}{l}\text { Migrant } \\
\text { sample }\end{array}$} & \multicolumn{2}{|c|}{$\begin{array}{l}\text { Non-migrant } \\
\text { sample }\end{array}$} \\
\hline & 2008 & 2009 & 2008 & 2009 & 2008 & 2009 & 2008 & 2009 \\
\hline Age & 31.3 & 32.2 & 40.0 & 40.6 & 29.3 & 29.8 & 42.9 & 43.3 \\
\hline $\begin{array}{l}\text { Percentage } \\
\text { of males }\end{array}$ & 58.3 & 57.9 & 53.9 & 52.8 & 61.8 & 60.6 & 51.8 & 50.8 \\
\hline \multicolumn{9}{|c|}{ Marital status (\%): } \\
\hline $\begin{array}{l}\text { First } \\
\text { marriage }\end{array}$ & 62.0 & 63.9 & 77.2 & 77.3 & 54.9 & 55.8 & 83.2 & 82.7 \\
\hline $\begin{array}{l}\text { Second } \\
\text { marriage }\end{array}$ & 0.8 & 0.9 & 2.2 & 2.8 & 1.5 & 1.8 & 2.3 & 3.0 \\
\hline Cohabitation & 0.3 & 0.7 & 0.4 & 0.4 & 0.1 & 0.4 & 0.5 & 0.4 \\
\hline Divorced & 1.0 & 1.2 & 0.4 & 0.5 & 0.6 & 0.7 & 0.3 & 0.4 \\
\hline Widowed & 0.4 & 0.6 & 1.0 & 1.0 & 0.3 & 0.1 & 1.2 & 1.3 \\
\hline Single & 35.4 & 32.7 & 18.8 & 18.0 & 42.5 & 41.3 & 12.4 & 12.2 \\
\hline $\begin{array}{l}\text { Years of } \\
\text { schooling }\end{array}$ & 9.1 & 9.2 & 7.5 & 7.5 & 8.5 & 8.5 & 7.2 & 7.2 \\
\hline \multicolumn{9}{|c|}{ Level of schooling (\%): } \\
\hline Illiterate & 2.1 & 4.0 & 4.9 & 4.9 & 0.7 & 0.8 & 6.1 & 6.0 \\
\hline $\begin{array}{l}\text { Primary } \\
\text { school }\end{array}$ & 12.9 & 12.1 & 17.6 & 17.7 & 7.6 & 7.4 & 20.3 & 20.3 \\
\hline $\begin{array}{l}\text { Junior high } \\
\text { school }\end{array}$ & 55.6 & 49.7 & 63.9 & 63.4 & 75.0 & 74.9 & 60.9 & 60.5 \\
\hline $\begin{array}{l}\text { Senior high } \\
\text { school }\end{array}$ & 25.5 & 27.6 & 13.5 & 13.9 & 16.7 & 16.8 & 12.7 & 13.1 \\
\hline $\begin{array}{l}\text { Post- } \\
\text { secondary }\end{array}$ & 4.0 & 6.6 & 0.0 & 0.0 & 0.0 & 0.1 & 0.0 & 0.0 \\
\hline $\begin{array}{l}\text { Total no. of } \\
\text { observations }\end{array}$ & 7153 & 7563 & 20451 & 20408 & 4317 & 4110 & 16134 & 16298 \\
\hline
\end{tabular}

Source: Authors' own survey.

Compared with the migrant sample surveyed in urban cities, the rural total labour force (including migrants and non-migrants) is much older. On average, they were forty and forty-one years of age in 2008 and 2009, respectively. Consistent with the migrant survey, the average age of the migrant population is about thirty years, while the non-migrant sample is much older (about fortythree). This age differential indicates that young people are more likely than older people to migrate. We present the age distributions from different samples in Figure 12.1, where it is clearly indicated that migrants are more concentrated in the twenty-thirty age group, whereas non-migrants are more concentrated in the late-thirty to fifty age group. 
Figure 12.1 Age distribution of the sample from the migrant and rural surveys
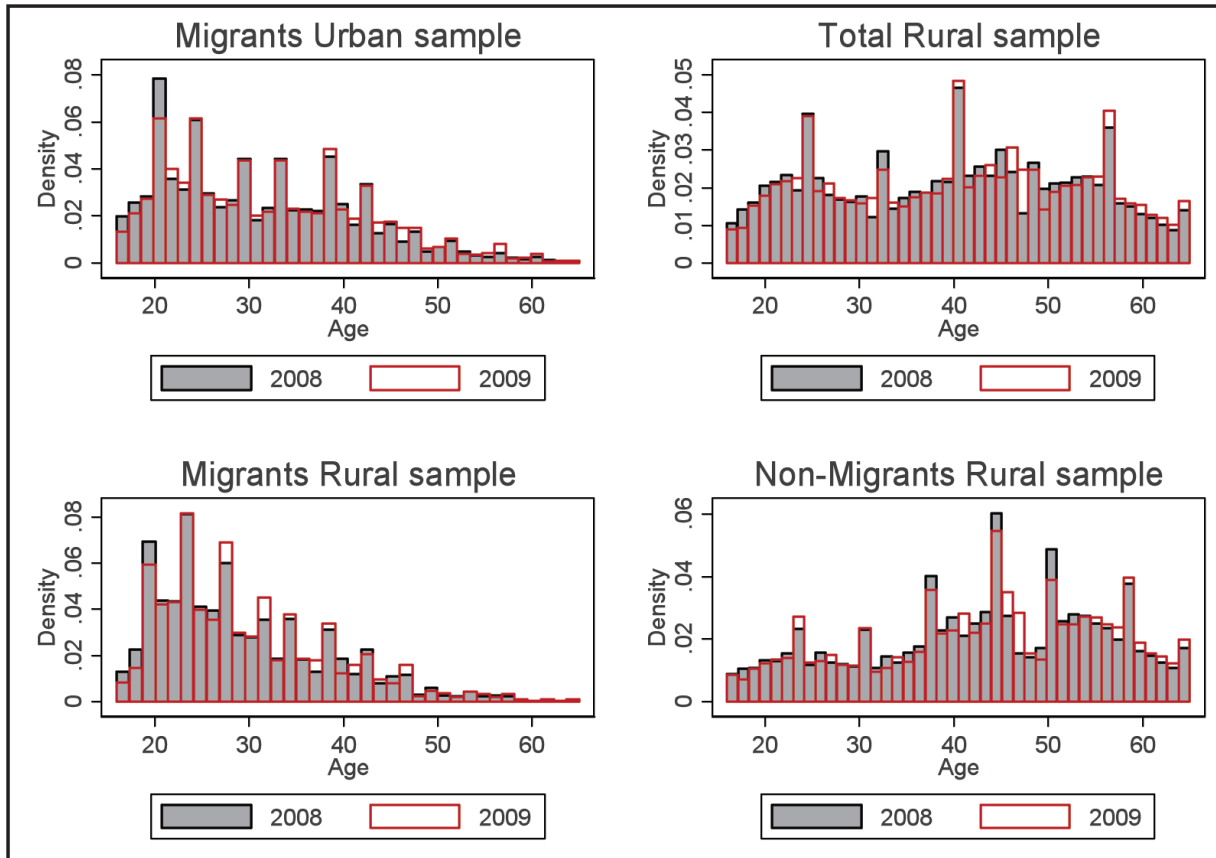

Source: Authors' own survey.

Migrants are also most likely to be males. In the total rural sample, about 53-54 per cent are males, while for the migrant sample the proportion is about 58 per cent; and for migrants in the rural sample it is even higher at about 61 per cent. Migrants are also more likely to be singles and divorcees. Finally, migrants are better educated than those who are non-migrants.

\section{The effect of the global financial crisis on labour-market outcomes: urban perspective}

In this section, we investigate the extent to which the global financial crisis affected the employment and wages of rural-urban migrants who stayed in cities during 2009.

Table 12.2 presents summary statistics of employment and wages for the two years as well as the differences in outcomes between the two years. The first panel of Table 12.2 shows that the employment rate for the total sample fell from 98.7 in 2008 to 96.6 in 2009 - that is, an increase in the unemployment rate by 2.1 percentage points. If we look at the panel sample, the increase in the unemployment rate is marginally higher - at 2.7 percentage points. Considering the huge reduction in exports during 2009, this increase in unemployment looks rather trivial. 
Table 12.2 Employment and earnings of migrants in cities (migrant sample)

\begin{tabular}{|c|c|c|c|c|c|c|c|}
\hline & & \multicolumn{3}{|c|}{ Total sample } & \multicolumn{3}{|c|}{ Panel sample } \\
\hline & & 2008 & 2009 & Difference & 2008 & 2009 & Difference \\
\hline \multirow{6}{*}{$\begin{array}{l}\text { Panel } \\
1\end{array}$} & Employed (\%) & 98.7 & 96.6 & -2.1 & 98.8 & 96.1 & -2.7 \\
\hline & Self-employed (\%) & 22.5 & 28.1 & 5.6 & 31.6 & 38.3 & 6.7 \\
\hline & $\begin{array}{l}\text { Wage and salary } \\
\text { earners }(\%)\end{array}$ & 72.1 & 69.7 & -2.4 & 61.5 & 59.3 & -2.2 \\
\hline & Family workers(\%) & 5.4 & 2.2 & -3.2 & 6.9 & 2.4 & -4.5 \\
\hline & $\begin{array}{l}\text { Total no. of } \\
\text { labour force }\end{array}$ & 7153 & 7567 & 414 & 2829 & 2714 & -115 \\
\hline & & 2008 & 2009 & $\begin{array}{l}\text { Percentage } \\
\text { change }(\%)\end{array}$ & 2008 & 2009 & $\begin{array}{l}\text { Percentage } \\
\text { change }(\%)\end{array}$ \\
\hline \multirow[t]{8}{*}{$\begin{array}{l}\text { Panel } \\
2\end{array}$} & $\begin{array}{l}\text { Weekly hours } \\
\text { worked (hour) }\end{array}$ & 63.1 & 63.1 & 0.0 & 65.8 & 65.5 & -0.5 \\
\hline & $\begin{array}{l}\text { Wage and } \\
\text { salary earners }\end{array}$ & 58.4 & 57.3 & -1.9 & 58.9 & 57.7 & -2.0 \\
\hline & Self-employed & 78.3 & 77.6 & -0.9 & 79.3 & 77.7 & -2.0 \\
\hline & Weekly hours & orked b & industr & & & & \\
\hline & Construction & 62.2 & 61.5 & -1.1 & 61.7 & 61.5 & -0.3 \\
\hline & Manufacturing & 54.6 & 55.2 & 1.1 & 55.7 & 55.0 & -1.3 \\
\hline & $\begin{array}{l}\text { Retail/wholesale } \\
\text { trade }\end{array}$ & 59.2 & 57.7 & -2.5 & 59.6 & 58.2 & -2.3 \\
\hline & Service & 58.8 & 57.4 & -2.4 & 59.1 & 58.5 & -1.0 \\
\hline \multirow[t]{7}{*}{$\begin{array}{l}\text { Panel } \\
3\end{array}$} & $\begin{array}{l}\text { Monthly } \\
\text { earnings } \\
\text { or net revenue } \\
\text { (RMB) }\end{array}$ & 1598 & 1820 & 13.9 & 1648 & 1842 & 11.8 \\
\hline & $\begin{array}{l}\text { Wage and } \\
\text { salary } \\
\text { earners }\end{array}$ & 1411 & 1631 & 15.6 & 1417 & 1661 & 17.2 \\
\hline & Self-employed & 2200 & 2297 & 4.4 & 2098 & 2128 & 1.4 \\
\hline & $\begin{array}{l}\text { Hourly earnings } \\
\text { or net revenue } \\
\text { RMB) }\end{array}$ & 6.4 & 7.5 & 17.2 & 6.41 & 7.64 & 19.2 \\
\hline & $\begin{array}{l}\text { Wage and } \\
\text { salary } \\
\text { earners }\end{array}$ & 6.2 & 7.4 & 19.4 & 6.2 & 7.6 & 22.6 \\
\hline & Self-employed & 7.3 & 7.9 & 8.2 & 6.8 & 7.7 & 13.2 \\
\hline & $\begin{array}{l}\text { First month } \\
\text { earnings or } \\
\text { net revenue } \\
\text { (RMB) }\end{array}$ & 899.6 & 978.1 & 8.7 & & & \\
\hline
\end{tabular}


The global financial crisis and rural-urban migration

\begin{tabular}{llccc|ccc}
\hline $\begin{array}{l}\text { Panel } \\
\mathbf{4}\end{array}$ & $\begin{array}{l}\text { Percentage } \\
\text { of workers } \\
\text { receiving } \\
\text { welfare } \\
\text { insurance (\%) }\end{array}$ & $\mathbf{2 0 0 8}$ & $\mathbf{2 0 0 9}$ & Difference & $\mathbf{2 0 0 8}$ & $\mathbf{2 0 0 9}$ & Difference \\
$\begin{array}{l}\text { Unemployment } \\
\text { insurance }\end{array}$ & 11.9 & 12.2 & 0.3 & 11.8 & 11.9 & 0.1 \\
$\begin{array}{l}\text { Pension } \\
\text { insurance }\end{array}$ & 18.9 & 20.6 & 1.7 & 19.7 & 20.8 & 1.1 \\
$\begin{array}{l}\text { Health } \\
\text { insurance }\end{array}$ & 55.9 & 68.2 & 12.3 & 59.8 & 67.9 & 8.1 \\
$\begin{array}{l}\text { Work injury } \\
\text { insurance }\end{array}$ & 17.5 & 16.8 & -0.7 & 16.6 & 16.8 & 0.2 \\
& 7.0 & 7.0 & 0 & 6.5 & 7.2 & 0.7 \\
\hline
\end{tabular}

Source: Authors' own survey.

Of the total employed, the proportion of self-employed increased by 5.6 percentage points for the total sample. This increase could, however, to some extent be a result of sample attrition bias, because self-employed individuals are less mobile than their wage/salary-earning counterparts and hence are more likely to be tracked in the second wave. To gauge the extent to which sample attrition could contribute to this increase in the share of self-employment, we further examine the panel sample. For the sample of the same individuals, we find that in 2008, 32 per cent were self-employed and by 2009, 38 per cent were self-employed - an increase of 6 percentage points. Switching from being a wage/salary earner to self-employment could have been a strategy to cope with the economic downturn generated by the global financial crisis. During the East Asian financial crisis (1998), many migrant workers in Indonesia switched from the formal sector to the informal sector (Hugo 2000). Indeed, when we compare occupational distributions for the self-employed in 2008 and 2009, we find that the biggest reduction between the two years is for small-shop or factory owners, while the biggest increases in 2009 are for street vendors, garbage collectors and shop assistants (see Appendix Table 12.A2). This last group is more likely to be categorised as informal-sector employment.

Another way to adjust employment in response to the economic shock is to reduce working hours. The second panel of Table 12.2 summarises the average weekly hours worked by total employed workers as well as by self-employed and wage/salary earners, separately. On average, there is hardly any change in weekly hours worked for the total sample and the panel sample. Self-employed workers in general work longer hours than wage/salary earners and this phenomenon did not change over time. More importantly, weekly hours worked did not fall much for either self-employed or wage/salary earners in 2009 relative to 2008. For the self-employed, there is a 1 per cent reduction in hours worked while the proportion for wage/salary earners is 1.9 per cent. Given the fact that the global financial crisis is more likely to have affected manufacturing rather than 
other industries, we also examine hours worked by industry (also see Figure 12.2). Here the same story is observed: the largest reduction in hours worked is 2.5 per cent for the retail/wholesale trades. The manufacturing industry had no observable decline in hours but rather a 1 per cent increase. Clearly, no job sharing occurred in the Chinese labour market during the recession, unlike the situation in some Western labour markets. This is understandable because in a country with an abundant labour supply at the unskilled level, employers would not have been worried about hiring when the recession was over.

\section{Figure 12.2 Wage/salary workers' log weekly hours worked by industry}

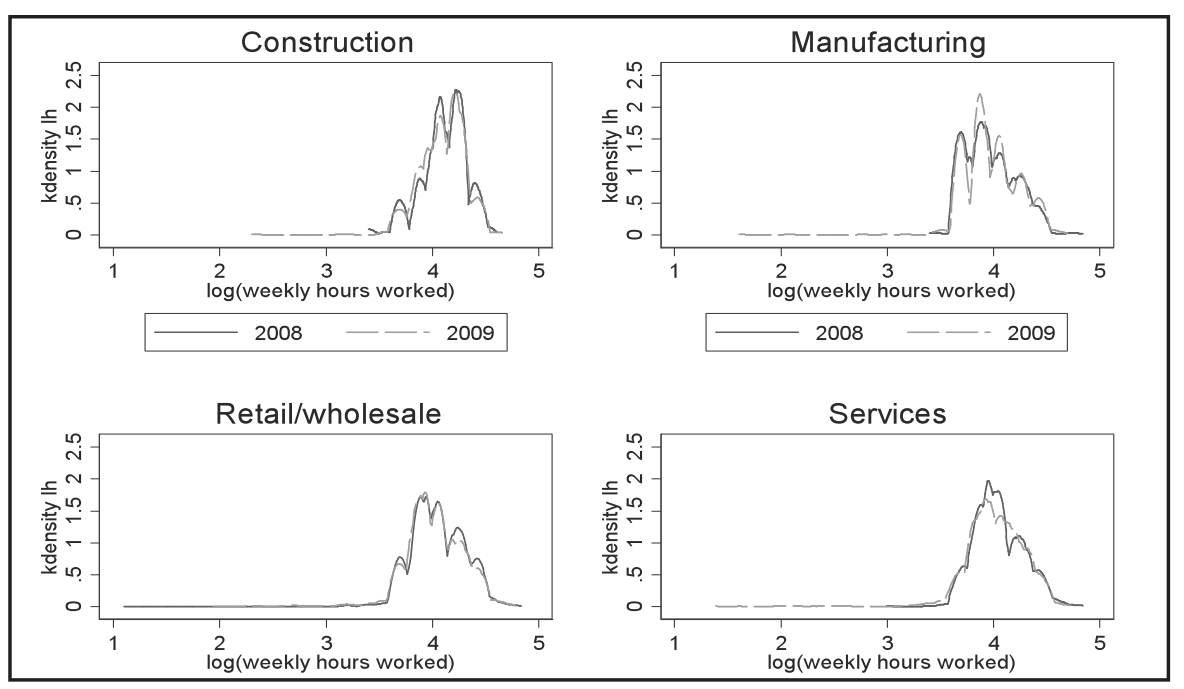

Source: Calculated based on authors' own survey.

The small change in the unemployment rate and the small change in hours worked between 2008 and 2009 suggest that the average employment situation for migrants who stayed in cities was not significantly affected. This is rather puzzling to us. Given the 20 per cent reduction in exports (MoHRSS 2009), one would have expected a much larger employment effect. Perhaps, as the labour market for migrant workers is flexible, the demand shock can be absorbed by the wage flexibility. If so, we should observe a downward change in earnings.

Panel 3 of Table 12.2 presents the change in monthly and hourly earnings for the total, wage/salary earners and self-employed workers for the total and panel samples. For monthly or hourly earnings, we observe no reduction, but rather an increase in earnings in 2009. Even more surprisingly, the largest increase in earnings occurred among wage/salary earners, who should have been the group most negatively affected by the global financial crisis shock. The average hourly earnings increase for wage/salary earners was 19 per cent, while for the selfemployed it was 8 per cent. Figure 12.3 presents the distribution of earnings by industries for wage/salary earners. It is clear that every industry had an hourly earnings increase between 2008 and 2009 and it is particularly so for the panel sample. 
Figure 12.3a Wage/salary earners' log hourly earnings by industry (total sample)

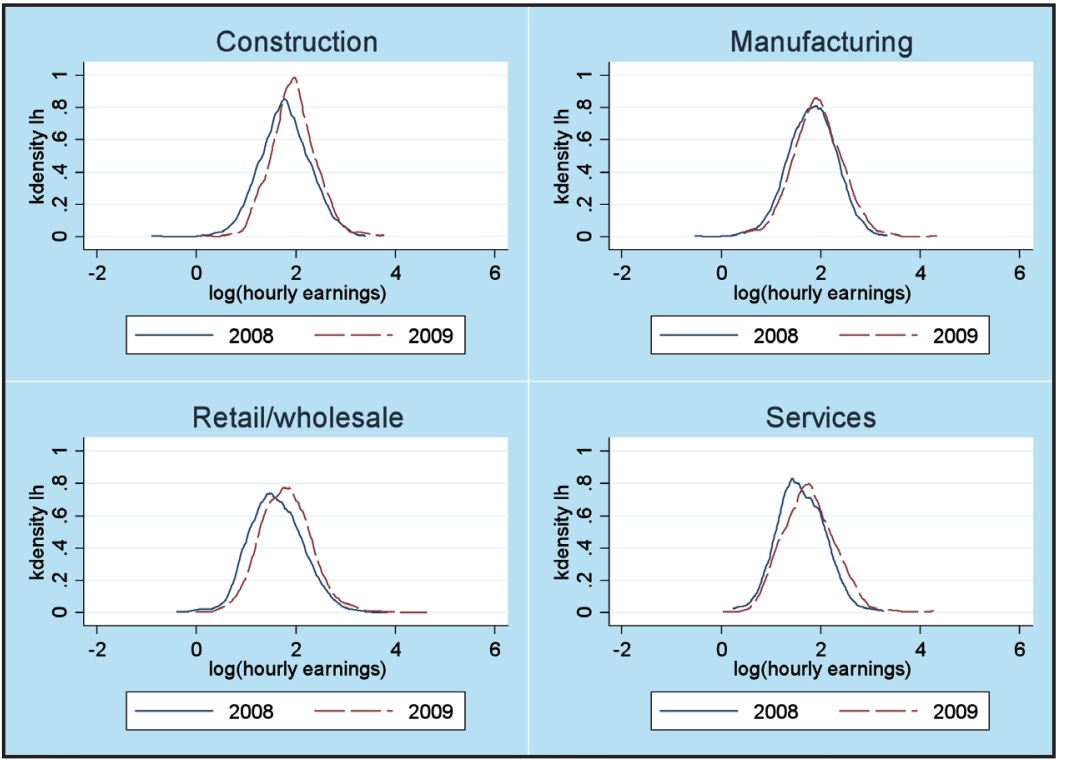

Figure 12.3b Wage/salary earners' log hourly earnings by industry (panel sample)

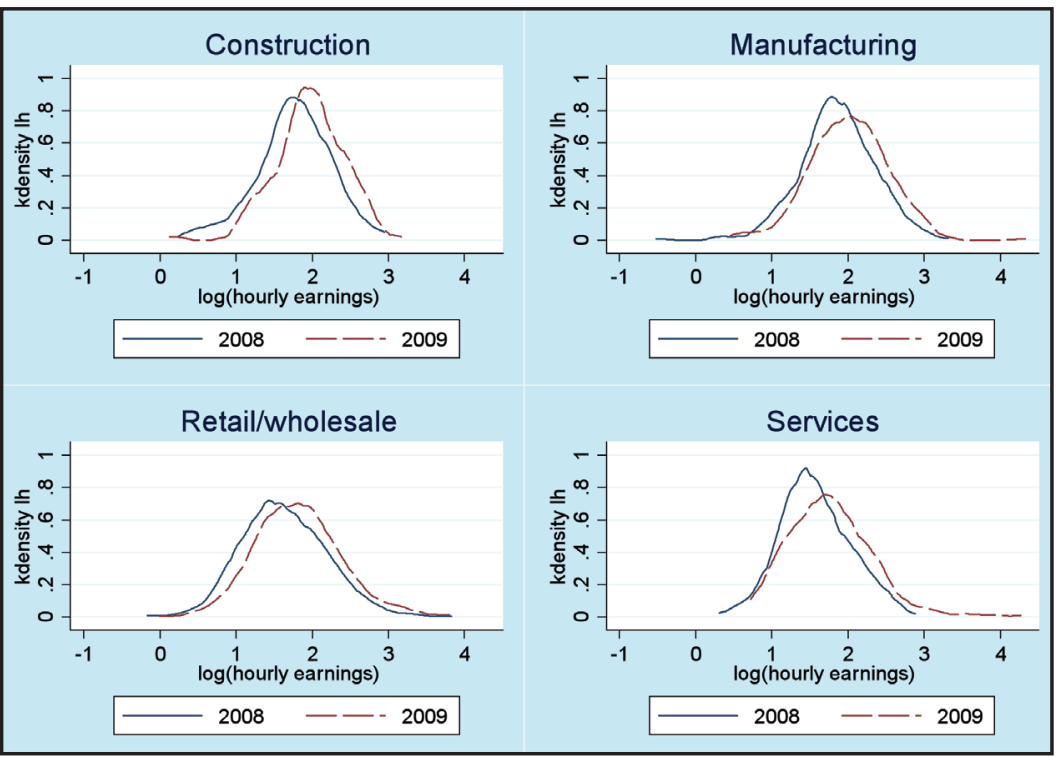

Source: Calculated based on authors' own survey.

We also examine whether monthly earnings for new arrivals changed between the two years in Panel 3 of Table 12.2. This is interesting because this group represents the most unskilled workers without any work experience. In the RUMiCI survey, we collect information on earnings in the first month of the first job. For those whose arrival month and survey month are the same or plus/ 
minus one month, we use their current monthly earnings. Many individuals did not report first-month earnings, especially those who arrived within the survey year. Thus, we have a rather small sample, with a total of 93 new arrivals for 2008 and 26 for 2009. On average, the first monthly pay for the first job is about 9 per cent higher in 2009 than in 2008.

Finally, we examine whether employer-provided social insurance has fallen as part of the adjustment for earnings levels (Panel 4 of Table 12.2). Here again we did not find much change and, if anything, the changes are positive.

The above analysis examines only average unconditional hours and earnings changes. To ascertain whether these results are due to the change in the distribution of different types of workers and their working locations between the two years, we estimate hours and earnings equations, which control for individual characteristics and industry and regional variations. Table 12.3 presents the regression results for log weekly work hours (first three columns) and log hourly earnings (columns 4-6). We estimate these regressions for the total sample and the sample of wage/salary earners and self-employed, separately.

Table 12.3 Results from the hours and hourly earnings equations for migrants in cities (migrant sample)

\begin{tabular}{|c|c|c|c|c|c|c|}
\hline & \multicolumn{3}{|c|}{ log (weekly work hours) } & \multicolumn{3}{|c|}{ log (hourly earnings) } \\
\hline & Total & $\begin{array}{l}\text { Wage/ } \\
\text { salary }\end{array}$ & $\begin{array}{c}\text { Self- } \\
\text { employed }\end{array}$ & Total & Wage/salary & $\begin{array}{c}\text { Self- } \\
\text { employed }\end{array}$ \\
\hline \multirow[t]{2}{*}{ Age } & -0.011 & -0.015 & 0.010 & 0.039 & 0.044 & 0.007 \\
\hline & {$[0.002]^{* * *}$} & {$[0.002]^{* * *}$} & {$[0.005]^{*}$} & {$[0.004]^{* * *}$} & {$[0.003]^{* * *}$} & [0.012] \\
\hline \multirow{2}{*}{$\begin{array}{l}\text { Age } \\
\text { squared/ } \\
100\end{array}$} & 0.014 & 0.021 & -0.013 & -0.062 & -0.069 & -0.021 \\
\hline & {$[0.003]^{* * *}$} & {$[0.003]^{* * *}$} & {$[0.006]^{* *}$} & {$[0.005]^{* * *}$} & {$[0.005]^{* * *}$} & [0.015] \\
\hline \multirow{2}{*}{$\begin{array}{l}\text { Years of } \\
\text { schooling }\end{array}$} & -0.016 & -0.018 & -0.007 & 0.048 & 0.053 & 0.036 \\
\hline & {$[0.001]^{* * *}$} & {$[0.002]^{* * *}$} & {$[0.004]^{* *}$} & {$[0.003]^{* * *}$} & {$[0.003]^{* * *}$} & {$[0.008]^{* * *}$} \\
\hline \multirow{2}{*}{$\begin{array}{l}\text { Years of } \\
\text { schooling* } \\
\text { dummy } \\
\text { for } 2009\end{array}$} & -0.005 & -0.013 & -0.004 & 0.069 & 0.009 & 0.073 \\
\hline & [0.019] & [0.020] & [0.046] & {$[0.038]^{*}$} & [0.036] & [0.110] \\
\hline \multirow{2}{*}{$\begin{array}{l}\text { Dummy } \\
\text { for males }\end{array}$} & 0.016 & 0.027 & -0.023 & 0.130 & 0.126 & 0.123 \\
\hline & {$[0.005]^{* * *}$} & {$[0.005]^{* * *}$} & {$[0.012]^{* *}$} & {$[0.010]^{* * *}$} & {$[0.009]^{* * *}$} & {$[0.028]^{* * *}$} \\
\hline $\begin{array}{l}\text { Dummy } \\
\text { for married }\end{array}$ & $\begin{array}{c}0.013 \\
{[0.007]^{*}}\end{array}$ & $\begin{array}{c}0.011 \\
{[0.007]}\end{array}$ & $\begin{array}{c}0.034 \\
{[0.021]}\end{array}$ & $\begin{array}{l}-0.006 \\
{[0.015]}\end{array}$ & $\begin{array}{l}-0.004 \\
{[0.013]}\end{array}$ & $\begin{array}{l}-0.059 \\
{[0.051]}\end{array}$ \\
\hline
\end{tabular}




\begin{tabular}{|c|c|c|c|c|c|c|}
\hline $\begin{array}{l}\text { Year since } \\
\text { first } \\
\text { migration }\end{array}$ & $\begin{array}{c}0.003 \\
{[0.001]^{* *}}\end{array}$ & $\begin{array}{c}0.004 \\
{[0.001]^{* * *}}\end{array}$ & $\begin{array}{c}0.002 \\
{[0.003]}\end{array}$ & $\begin{array}{c}0.027 \\
{[0.003]^{* * *}}\end{array}$ & $\begin{array}{c}0.025 \\
{[0.002]^{* * *}}\end{array}$ & $\begin{array}{c}0.026 \\
{[0.007]^{* * *}}\end{array}$ \\
\hline $\begin{array}{l}\text { Year } \\
\text { since first } \\
\text { migration } \\
\text { squared/ } \\
100\end{array}$ & $\begin{array}{c}-0.010 \\
{[0.005]^{* *}}\end{array}$ & $\begin{array}{c}-0.014 \\
{[0.005]^{* * *}}\end{array}$ & $\begin{array}{l}-0.004 \\
{[0.011]}\end{array}$ & $\begin{array}{c}-0.079 \\
{[0.010]^{* * *}}\end{array}$ & $\begin{array}{c}-0.064 \\
{[0.010]^{* * *}}\end{array}$ & $\begin{array}{c}-0.090 \\
{[0.026]^{* * *}}\end{array}$ \\
\hline $\begin{array}{l}\text { Dummy } \\
\text { for self- } \\
\text { employed }\end{array}$ & $\begin{array}{c}0.243 \\
{[0.007]^{* * *}}\end{array}$ & & & $\begin{array}{c}0.042 \\
{[0.013]^{* * *}}\end{array}$ & & \\
\hline $\begin{array}{l}\text { Dummy } \\
\text { for } 2009\end{array}$ & $\begin{array}{l}-0.014 \\
{[0.018]}\end{array}$ & $\begin{array}{l}-0.005 \\
{[0.020]}\end{array}$ & $\begin{array}{l}-0.023 \\
{[0.040]}\end{array}$ & $\begin{array}{c}0.056 \\
{[0.036]}\end{array}$ & $\begin{array}{c}0.153 \\
{[0.035]^{* * *}}\end{array}$ & $\begin{array}{l}-0.051 \\
{[0.096]}\end{array}$ \\
\hline $\begin{array}{l}\text { Industry } \\
\text { dummies }\end{array}$ & Yes & Yes & Yes & Yes & Yes & Yes \\
\hline $\begin{array}{l}\text { City } \\
\text { dummies }\end{array}$ & Yes & Yes & Yes & Yes & Yes & Yes \\
\hline $\begin{array}{l}\text { Obser- } \\
\text { vations }\end{array}$ & 13149 & 9777 & 3372 & 13149 & 9777 & 3372 \\
\hline R-squared & 0.23 & 0.11 & 0.05 & 0.22 & 0.33 & 0.13 \\
\hline
\end{tabular}

* significant at 10 per cent

** significant at 5 per cent

*** significant at 1 per cent

Note: Standard errors are in brackets.

Source: Authors' own estimations.

Controlling for city and industry effects, most of the demographic characteristics seem to exhibit normal patterns in both the hours and earnings equations. We discuss the hours equation first. For the total sample, age has a U-shaped relationship with hours worked. This is the same as for wage/salary earners, but for self-employed the relationship is reversed. The more educated an individual is the fewer hours he/she works and this relationship does not change between the two years. Males work 2-3 per cent more hours than their female counterparts if they are a wage/salary earner, but 2 per cent less if they are selfemployed. Married workers work slightly longer hours and the relationship between years since migration and hours worked is inverse U-shaped. Selfemployed workers on average work 24 per cent more than wage/salary earners. Finally, standardising for individual, industry and regional effects, workers in 2009 worked almost the same number of hours a week as they did in 2008. 
Moving to the log hourly earnings equations, we find the normal inverse U-shaped relationship between age and earnings. An additional year of schooling increases earnings for wage/salary earners by 5.3 per cent and for the selfemployed by 3.6 per cent. These rates of return do not seem to change over time. The number of years since migration also has an inverse U-shaped relationship with earnings. The self-employed earn 4.2 per cent more hourly earnings than wage/salary earners. Controlling for all these characteristics, hourly earnings in 2009 do not seem to be statistically different from those in 2008 for the total sample. This, however, is not the case for wage/salary earners. For this group of workers, their hourly earnings increased by 15 per cent conditional on other co-variates. The self-employed, on the other hand, earned 5 per cent less but the point estimate is not statistically significant.

Combining the stories on unemployment, hours worked and earnings changes, it seems that at the time of the global financial crisis, those migrant workers who did not lose their jobs or could find other jobs were not adversely affected in terms of hours worked - and their earnings were not adversely affected. In fact, for wage/salary earners, their earnings increased by 15 per cent. This seems to suggest that the labour-market flexibility for migrant wage/salary earners could be reflected in hiring and firing. On the other hand, the self-employed sector does seem to have more labour-market flexibility, where we observe increased informal employment, slight reduction in hours worked and slight reduction in hourly earnings.

\section{The effect of the global financial crisis on labour-market outcomes: rural perspective}

In the previous section, we examined labour-market outcomes for migrants who remained in cities during the global financial crisis. In this section, we use the rural household sample to investigate the possible effect of the global financial crisis on return migration, rural off-farm employment and earnings.

Table 12.4 presents summary statistics on employment and migration. Between 2008 and 2009, the total number of the rural labour force in our sample fell by only 42 people. Note that here 'rural labour force' is defined as those aged sixteen to sixty-five who are either employed or unemployed, including those who have already migrated but still have household registration in their rural village, which is the majority of migrants. Of those in the labour force, 97.7 and 98.9 per cent are employed in the two years, respectively - that is, a reduction in the unemployment rate of 1.2 percentage point for that period (Panel 1 of Table 12.4). ${ }^{3}$ 
The global financial crisis and rural-urban migration

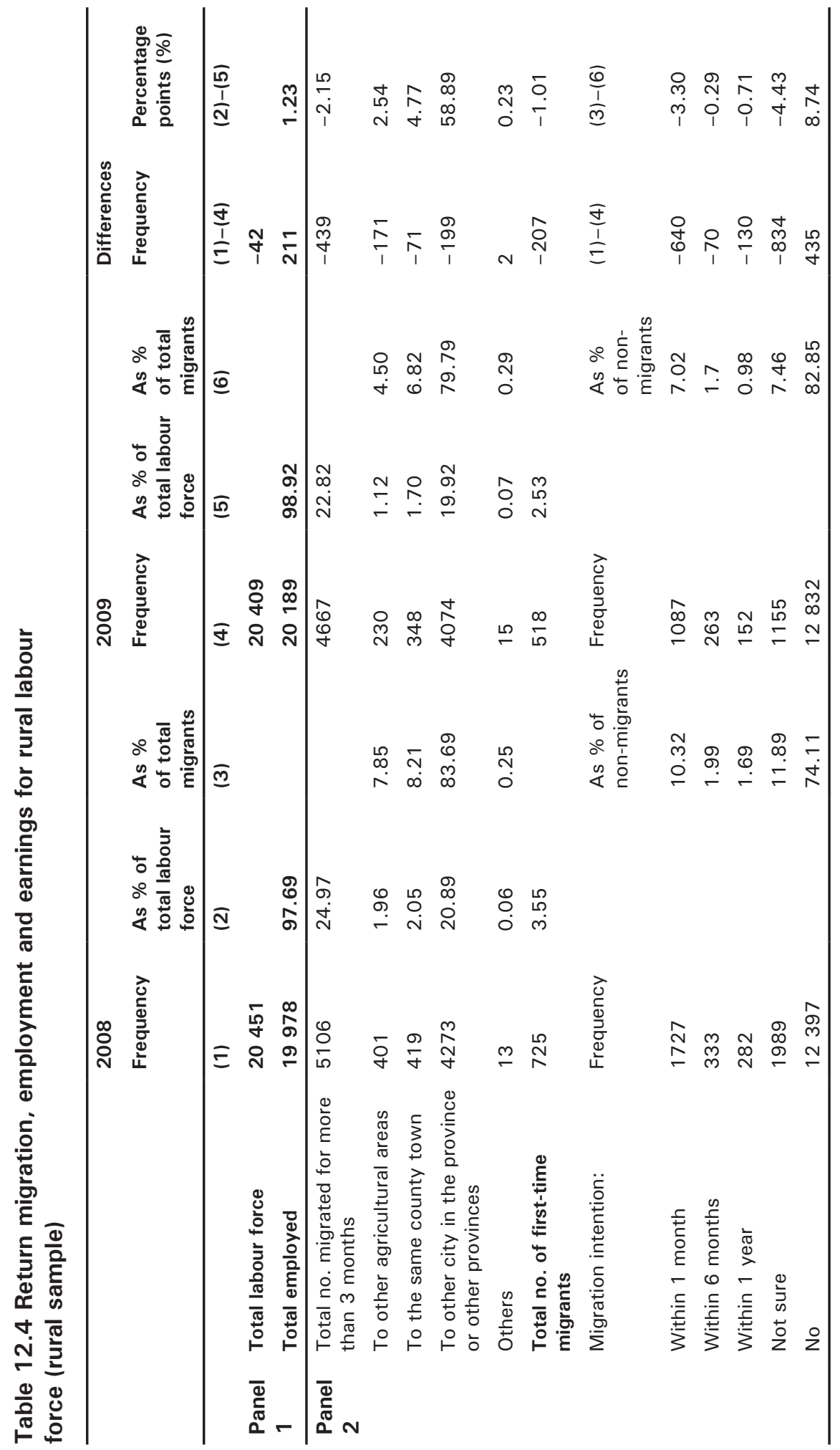


China: The Next Twenty Years of Reform and Development

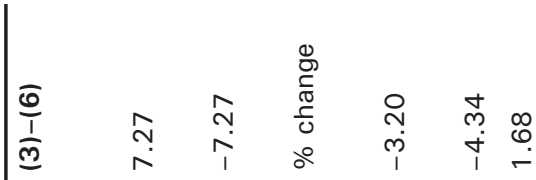

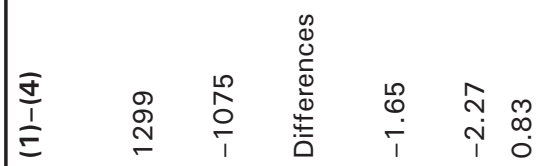

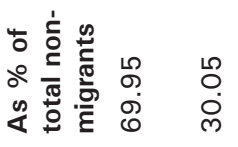

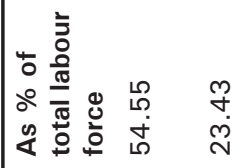

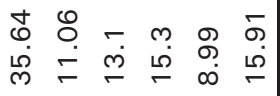

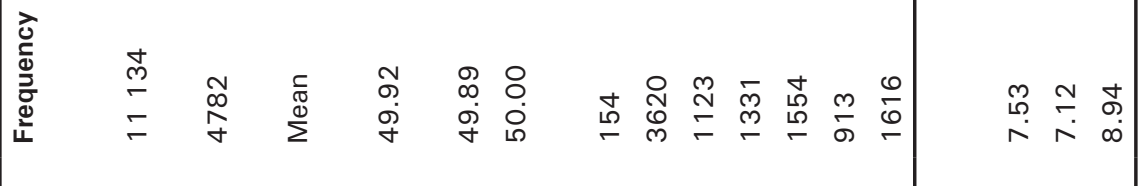

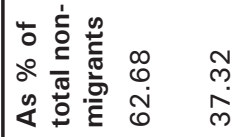

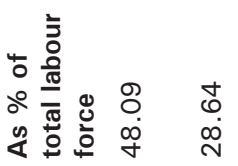

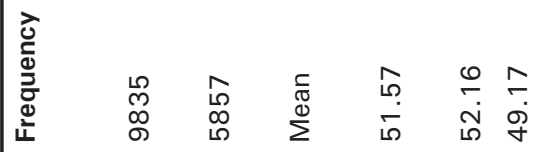

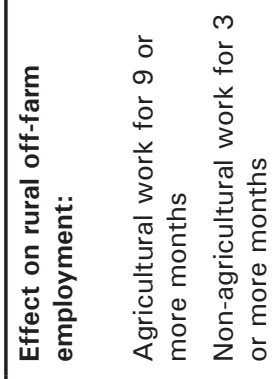

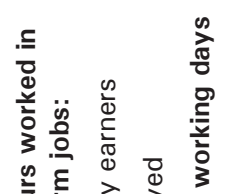

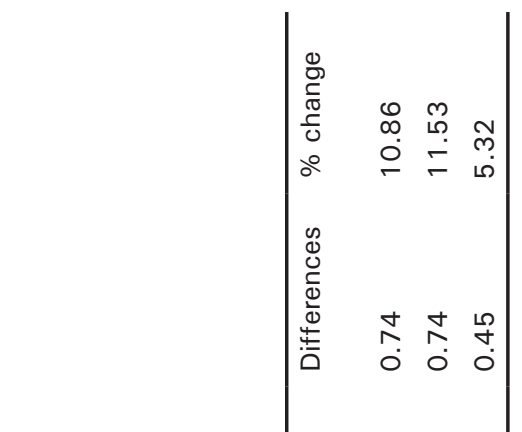

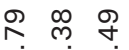

$$
\begin{aligned}
& \text { ( }) \\
& \text { ब }
\end{aligned}
$$

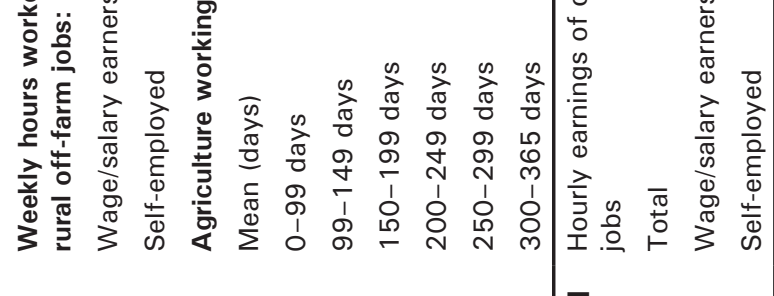

$$
\begin{aligned}
& \text { ब }
\end{aligned}
$$


Of the total labour force, about 25 per cent in 2008 and 23 percent in 2009 migrated to other places to work - a total 2.2 percentage point reduction. Relative to 2008, in 2009, the proportion of migrants fell by 8.6 per cent from 5106 to 4667 . We further divide the migrants into four different categories: those who migrated to other rural regions, to local county towns, to other cities in the province or other provinces, and to other places. In both years, the largest group is those who migrated to other cities within the province or other provinces and this is the group we use to identify migrants in our urban migrant sample. This group accounted for 84 and 80 per cent of the total migrants in 2008 and 2009, respectively, or a reduction of 4 percentage points (Panel 2 of Table 12.4).

Because of the panel nature of our data, we are able to examine the number of people who migrated in 2008 but did not migrate in 2009 and those who migrated in 2009 but did not migrate in 2008 (the top panel of Table 12.5). The former has 1371 individuals and the latter has 1189 individuals. Thus, we have a net return migration of 182 people, which accounted for 4.3 per cent of the total migrants in 2009 , translating to about 6.5 million people at the national level. Note that in a normal year we would have observed a net increase in migration. For example, based on the World Bank (2009), between 2004 and 2005 the number of migrants increased - from 118.2 million to 125.8 millionan increase of 6.4 per cent. Therefore, the 6.5 million observed net reduction in migration is only a lower-bound estimate of the effect of the global financial crisis on migration. If we regard the change between 2004 and 2005 as a normal year, the real return migration between 2008 and 2009 should be no lower than 10 per cent of the total migrants - or a total of no less than 14-15 million migrants. Note that this estimate excludes temporary return migrants. Perhaps this is why this estimate is slightly lower than Kong et al.'s (2009) lower-bound estimate of the effect of the global financial crisis of 13 per cent.

Table 12.5 Migration and off-farm status for a panel of individuals (rural sample)

\begin{tabular}{|c|c|c|c|}
\hline & $\begin{array}{l}\text { No in } 2009 / \\
\text { yes in } 2008\end{array}$ & $\begin{array}{c}\text { Yes in } 2009 / \\
\text { no in } 2008\end{array}$ & Net difference \\
\hline Migration & (1) & (2) & $(3)=(1)-(2)$ \\
\hline Frequency & 1371 & 1189 & 182 \\
\hline $\begin{array}{l}\text { As percentage of } 2009 \\
\text { migrated labour }\end{array}$ & 32.5 & 28.2 & 4.3 \\
\hline \multicolumn{4}{|l|}{ Off-farm } \\
\hline Frequency & 2537 & 1431 & 1106 \\
\hline $\begin{array}{l}\text { As percentage of } 2009 \text { off- } \\
\text { farm labour }\end{array}$ & 53.0 & 29.9 & 23.1 \\
\hline $\begin{array}{l}\text { As percentage of } 2009 \text { total } \\
\text { labour force }\end{array}$ & 12.4 & 7.0 & 5.4 \\
\hline
\end{tabular}

Source: Based on authors' own surveys. 
Of the reduction in out-migration, we further investigate the effect of the global financial crisis on first-time migration and on migration intention (the second block in Panel 2 of Table 12.4). RUMiCI data include information on the year of first migration. Comparing the two periods-January 2007 to mid 2008 and January 2008 to mid 2009 - the number of first-time migrants dropped from 725 to 518 people, equivalent to a decrease of 1 percentage point of the total rural labour force. ${ }^{4}$ The former period can reasonably be considered as normal circumstances and used as a benchmark to compare with the latter, which covers the short period leading up to the height of the crisis through until the power of the crisis started to subside. The drop of 1 percentage point implies a decline of about five million first-time rural migrants. ${ }^{5}$

With regard to migration intentions, the survey asks individuals who were present at the time of the survey to indicate their plan to out-migrate. Compared with a year earlier, the numbers of adults who expected to migrate within one month, six months and one year all fell, while those indicating that they would not migrate increased substantially, from 74 to 83 per cent (the third block in Panel 2 of Table 12.4). As the 2009 survey was conducted mainly in the first half of the year, it is likely that the memory of the negative shock at the end of 2008 and the bleak prospects for employment discouraged rural labourers from becoming migrant workers.

The data presented above indicate a substantial effect of the global financial crisis on migration outflow. A net effect of no less than 10 per cent of the total migrants returned to their hometowns during late 2008 and stayed there through the first half of 2009.

What did these migrants do after they returned to the rural areas? Was it rural farming or off-farm employment that eventually absorbed these return migrants? How did the switching from out-migration to rural off-farm or farm work affect their earnings?

First, we investigate whether the 2009 return migrants were employed in farming or off-farm sectors. We find that 80 per cent of the migrants returned to a farming job and only 20 per cent returned to work in an off-farm job.

Second, we examine the change in farming and off-farm employment over the two years (the first block in Panel 3 of Table 12.4). We find that for those who did not migrate, the proportion working in the agricultural sector relative to the total non-migrated labour force increased by 7.27 percentage points (or 6.24 percentage points in terms of the total labour force with rural hukou) and

4 In this chapter, we define total rural labour as the labour force with rural household registration.

5 This is calculated based on the total labour force with rural household registration (rural hukou) using 20051 per cent population survey data. This number in 2005 was 505 million. 
the same degree of reduction is found for those who worked in the off-farm sector. Among those who worked in rural areas, we also utilise the panel nature of the data to examine the number of people who switched from an off-farm job in 2008 to farming employment in 2009 (the bottom panel of Table 12.5). There are 2537 individuals working in off-farm jobs in 2008 who switched to farm jobs in 2009, while only 1431 individuals moved from farming jobs to offfarm jobs - a net switch to farming jobs of 1106 individuals or 5.4 per cent of the total rural hukou labour force, which is equivalent to 27.3 million people. This, however, might be a lower-bound estimate. Assuming that in the preglobal financial crisis period rural off-farm employment increased annually by 2 percentage points, the real effect of the global financial crisis on rural offfarm jobs should be no less than 7.5 per cent of the total labour force with rural hukou - equivalent to 38 million rural hukou holders. This is a much bigger effect than the direct return migration effect. Perhaps, in addition to the direct demand shock of the global financial crisis, there is a secondary multiplier effect of return migration. When a large number of migrants lost jobs in the cities and returned to home villages, their income level fell, which in turn reduced demand for non-agricultural goods and services in the rural areas, leading to the multiplier effect on rural off-farm employment.

Based on our panel estimates, if we add the impact of the global financial crisis on return migration and on the switching from rural off-farm to farming jobs, total off-farm employment fell by 53 million (15 million return migrants plus 38 million switching from off-farm jobs to farming jobs) in $2009 .{ }^{6}$ This is a substantial employment effect.

Next, we consider whether for rural off-farm jobs there were any hourly adjustments (the second block in Panel 3 of Table 12.4). We find that there were slight reductions in the number of hours worked weekly in 2009 relative to 2008 for the wage/salary earners, but not for self-employed. For the former, the reduction was about 2.3 hours, or 4 per cent. This slight reduction in hours worked for wage/salary earners does not, however, take into account changes in individual characteristics or industry and regional distributions. Once controlling for these changes, there was no change in hours worked for either group (see Table 12.6 for the regression results).

6 The lower-bound estimate is 34 million (the 6.5 million return migration plus 27 million reduction in rural off-farm jobs). 
China: The Next Twenty Years of Reform and Development

Table 12.6 Results from hours and hourly earnings equations for rural off-farm work (rural sample)

\begin{tabular}{|c|c|c|c|c|c|c|}
\hline \multicolumn{4}{|c|}{ log(weekly hours worked) } & \multicolumn{3}{|c|}{ log(hourly earnings) } \\
\hline & Total & $\begin{array}{l}\text { Wage/ } \\
\text { salary }\end{array}$ & $\begin{array}{c}\text { Self- } \\
\text { employed }\end{array}$ & Total & Wage/salary & $\begin{array}{c}\text { Self- } \\
\text { employed }\end{array}$ \\
\hline \multirow[t]{2}{*}{ Age } & -0.004 & -0.006 & 0.007 & 0.037 & 0.03 & 0.073 \\
\hline & [0.003] & [0.004] & {$[0.011]$} & {$[0.005]^{* * *}$} & {$[0.005]^{* * *}$} & {$[0.015]^{* * *}$} \\
\hline \multirow{2}{*}{$\begin{array}{l}\text { Age squared } \\
/ 100\end{array}$} & -0.002 & 0.001 & -0.015 & -0.052 & -0.044 & -0.095 \\
\hline & {$[0.004]$} & [0.004] & [0.013] & {$[0.006]^{* * *}$} & {$[0.006]^{* * *}$} & {$[0.017]^{* * *}$} \\
\hline \multirow{2}{*}{$\begin{array}{l}\text { Years of } \\
\text { schooling }\end{array}$} & 0.004 & 0.002 & 0.012 & 0.024 & 0.028 & 0.002 \\
\hline & & [0.003] & {$[0.007]^{*}$} & {$[0.004]^{* * *}$} & {$[0.004]^{* * *}$} & [0.010] \\
\hline $\begin{array}{l}\text { Years of } \\
\text { schooling* } \\
\text { dummy } \\
\text { for } 2009\end{array}$ & $\begin{array}{c}-0.007 \\
{[0.004]^{*}}\end{array}$ & $\begin{array}{c}-0.007 \\
{[0.004]^{*}}\end{array}$ & $\begin{array}{l}-0.001 \\
{[0.011]}\end{array}$ & $\begin{array}{c}0.013 \\
0.005]^{* *}\end{array}$ & $\begin{array}{c}0.012 \\
{[0.005]^{* *}}\end{array}$ & $\begin{array}{c}0.018 \\
{[0.014]}\end{array}$ \\
\hline $\begin{array}{l}\text { Dummy for } \\
\text { males }\end{array}$ & $\begin{array}{c}0.01 \\
{[0.011]}\end{array}$ & $\begin{array}{c}0.006 \\
{[0.011]}\end{array}$ & $\begin{array}{c}0.012 \\
{[0.030]}\end{array}$ & $\begin{array}{c}0.274 \\
{[0.015]^{* * *}}\end{array}$ & $\begin{array}{c}0.259 \\
{[0.016]^{* * *}}\end{array}$ & $\begin{array}{c}0.319 \\
{[0.040]^{* * *}}\end{array}$ \\
\hline $\begin{array}{l}\text { Dummy } \\
\text { for married }\end{array}$ & $\begin{array}{c}0.052 \\
{[0.020]^{* * *}}\end{array}$ & $\begin{array}{c}0.047 \\
{[0.019]^{* *}}\end{array}$ & $\begin{array}{c}0.081 \\
{[0.077]}\end{array}$ & $\begin{array}{c}0.007 \\
{[0.028]}\end{array}$ & $\begin{array}{c}0.037 \\
{[0.028]}\end{array}$ & $\begin{array}{l}-0.134 \\
{[0.103]}\end{array}$ \\
\hline $\begin{array}{l}\text { Dummy for } \\
\text { self- } \\
\text { employed }\end{array}$ & $\begin{array}{c}-0.058 \\
{[0.013]^{* * *}}\end{array}$ & & & $\begin{array}{c}0.239 \\
{[0.019]^{* * *}}\end{array}$ & & \\
\hline $\begin{array}{l}\text { Dummy } \\
\text { for } 2009\end{array}$ & $\begin{array}{c}0.043 \\
{[0.031]}\end{array}$ & $\begin{array}{c}0.026 \\
{[0.032]}\end{array}$ & $\begin{array}{c}0.064 \\
{[0.088]}\end{array}$ & $\begin{array}{l}-0.013 \\
{[0.044]}\end{array}$ & $\begin{array}{l}-0.006 \\
{[0.046]}\end{array}$ & $\begin{array}{l}-0.05 \\
{[0.118]}\end{array}$ \\
\hline Observations & 9508 & 7444 & 2064 & 9508 & 7444 & 2064 \\
\hline R-squared & 0.06 & 0.06 & 0.06 & 0.13 & 0.13 & 0.12 \\
\hline
\end{tabular}

* significant at 10 per cent

** significant at 5 per cent

*** significant at 1 per cent

Note: Standard errors are in brackets.

Source: Authors' own estimations.

Considering that the land-labour ratio is very low in rural China and is probably fixed over the two-year period, an increase in the agricultural labour force should imply an increase in under-employment. To illustrate the level of under-employment among agricultural labour, we utilise the 2009 survey question, 'How many days in 2008 did you work on the farm?'. On average, 
those who identified themselves as having a farming job worked 154 days or 42 per cent of the year on the farm if using 365 days as the denominator and 52 per cent if using 300 days $^{7}$ as the denominator. Among the agricultural workers, 36 per cent worked only between zero and 99 days on the farm, while those who worked more than 200 days accounted for 40 per cent. The average total number of days this group worked on off-farm activities was 8.4 days (the third block in Panel 3 of Table 12.4). If we restrict the sample to those who identified themselves as working in the farming sector in both 2008 and 2009-a stronger indication of the agricultural workers - the average hours worked in the farming sector increased slightly to 172 , or 57 per cent of the year, using 300 days as the denominator. These data are indicative of the level of under-employment there has been in the rural agricultural sector.

The last important point to be investigated is whether wages for rural off-farm jobs were affected by the global financial crisis (see Panel 4 of Table 12.4). Interestingly, hourly earnings of both wage/salary earners and self-employed increased during this period. For the former, the hourly earnings increased by almost 12 per cent, while for the latter the increase was about 5 per cent. Once we control for demographic, industry and regional characteristics, however, the earnings change for rural off-farm workers between two years disappears (see Table 12.6).

It would be interesting to examine household-level income effects of the global financial crisis, but unfortunately our survey records only household income for previous years. Thus, we have only household income for 2007 and 2008, which does not allow us to investigate the effect of the global financial crisis. Using household income for 2008 for different types of households, we could, however, provide some indicative information of the impact of the reduction in migration and off-farm jobs on household per capita income. Table 12.7 presents these data. In 2008, rural households on average had a per capita income level of RMB9428. We divide these households into four types: 1) those with both migrants and rural off-farm workers; 2) those with rural off-farm workers but no migrants; 3) those with migrants but no off-farm workers; and 4) those with only farm workers. Comparing the average per capita household income for the first three types of households with households that have only farm workers, we find that farm work provides the lowest income. Surprisingly, though, rural off-farm workers seem to provide higher income to households than migrants. This perhaps is because rural off-farm workers are mainly living at home and hence all their income is counted as part of household income, whereas only the remittance component of migrant income is counted as part of household income. On average, the first three types of households have per capita income between 7 and 27 per cent higher than households with only farm workers.

7 That is, 300 working days is a normal migrant worker's annual working days in a city. 
Table 12.7 Per capita income comparisons across different type of households

\begin{tabular}{|c|c|c|c|c|}
\hline & \multirow[t]{2}{*}{$\begin{array}{c}\text { No. of } \\
\text { households }\end{array}$} & \multirow[t]{2}{*}{$\begin{array}{c}\text { Per } \\
\text { capita } \\
\text { income } \\
\text { (RMB) }\end{array}$} & \multicolumn{2}{|c|}{$\begin{array}{l}\text { Difference to } \\
\text { households } \\
\text { with only farm } \\
\text { workers }\end{array}$} \\
\hline & & & $\begin{array}{l}\text { Value } \\
\text { (RMB) }\end{array}$ & $\%$ difference \\
\hline Total households & 7912 & 9428 & 1001 & 11.9 \\
\hline $\begin{array}{l}\text { Households with both } \\
\text { off-farm and migrant } \\
\text { workers (1) }\end{array}$ & 657 & 10688 & 2261 & 26.8 \\
\hline $\begin{array}{l}\text { Households with off-farm } \\
\text { workers but no migrants (2) }\end{array}$ & 2896 & 10237 & 1810 & 21.5 \\
\hline $\begin{array}{l}\text { Households with migrants } \\
\text { but no off-farm workers (3) }\end{array}$ & 2004 & 9024 & 597 & 7.1 \\
\hline $\begin{array}{l}\text { Households with neither } \\
\text { off-farm nor migrant } \\
\text { workers (4) }\end{array}$ & 2355 & 8427 & & \\
\hline \multicolumn{5}{|l|}{2009 household type } \\
\hline 2008 household type & $\begin{array}{c}\text { Households } \\
\text { with both off- } \\
\text { farm and migrant } \\
\text { workers (1) }\end{array}$ & $\begin{array}{c}\text { Households } \\
\text { with off-farm } \\
\text { workers but } \\
\text { no migrants }(2)\end{array}$ & $\begin{array}{l}\text { Households } \\
\text { with } \\
\text { migrants } \\
\text { but no } \\
\text { off-farm } \\
\text { workers (3) }\end{array}$ & $\begin{array}{l}\text { Households } \\
\text { with neither } \\
\text { off-farm nor } \\
\text { migrant } \\
\text { workers (4) }\end{array}$ \\
\hline $\begin{array}{l}\text { Households with both } \\
\text { off-farm and migrant } \\
\text { workers (1) }\end{array}$ & 237 & 106 & 249 & 69 \\
\hline $\begin{array}{l}\text { Households with } \\
\text { off-farm workers but no } \\
\text { migrants (2) }\end{array}$ & 104 & 1803 & 265 & 748 \\
\hline $\begin{array}{l}\text { Households with migrants } \\
\text { but no off-farm workers ( } 3 \text { ) }\end{array}$ & 188 & 136 & 1353 & 367 \\
\hline $\begin{array}{l}\text { Households with neither } \\
\text { off-farm nor migrant } \\
\text { workers (4) }\end{array}$ & 30 & 430 & 174 & 1759 \\
\hline $\begin{array}{l}\text { Total no. of } \\
\text { households }\end{array}$ & 559 & 2475 & 2041 & 2943 \\
\hline $\begin{array}{l}\text { Percentage transited } \\
\text { from other types of } \\
\text { households }\end{array}$ & 57.6 & 27.1 & 33.7 & 40.2 \\
\hline
\end{tabular}

Source: Authors' own survey.

To gauge the degree of the income effect of the reduction in migration and rural off-farm jobs, we also present the transition matrix between 2008 and 2009 across the four types of households (second panel of Table 12.7). The bottom line is that in 2008, 2393 households had only agricultural workers and this figure increased to 2943 in 2009. In addition, 40 per cent (1184) of these 2943 
households had off-farm or migrant workers in 2008. It can be expected that these 1184 households suffered from the global financial crisis in terms of their reduced income levels.

\section{Conclusions}

This chapter examines the effect of the global financial crisis on the labourmarket outcomes of migrants from the perspective of those who remained in cities during the crisis and those who returned to their rural home villages.

Surprisingly, we found that migrants who decided to stay in cities in 2009 suffered very little in terms of employment, working hours and earnings.

To resolve this puzzle, we searched further and examined the employment and earnings conditions of the rural labour force. It was here in rural villages that we observed the most significant employment effect of the global financial crisis: no less than 15 million rural migrants (more than 10 per cent of total migrants) returned to rural villages in 2009. About 80 per cent of them went back to the rural farming sector, where they worked, on average, 52 per cent of the year. In addition to the effect of the global financial crisis on return migration, we found that rural off-farm employment fell by about 38 million - or 7.5 per cent of the total rural hukou labour force. Once again, for those employed in rural off-farm jobs, no downward adjustment to hours or earnings was detected.

Based on these findings, we are inclined to believe that the rural agricultural sector provided the employment buffer for return migration and rural off-farm employment during the global financial crisis. Because of this buffer effect, no open unemployment can be observed. In the current environment, this is certainly a good thing for political stability, although it has come at the expense of a reduction in agricultural productivity.

In the long run, however, it must be expected that small-scale farming will give way to large landholding and higher agricultural productivity. This inevitably will lead to the consolidation of farmland and many small landholders will need to sell their land. Thus, their future employment shocks will have to be cushioned by other means. The question is how will this be done? How will China move towards a universal welfare system and give migrants the rights to sell their land, effectively trading an inefficient land-based traditional welfare system for one that is more appropriate for a modern economy? In the decades ahead, policymakers' responses to this question will have a serious impact on the wellbeing of Chinese migrants - all hundreds of millions of them! 
China: The Next Twenty Years of Reform and Development

Appendix Table 12.A1 Migrant survey timing distribution by survey year (migrant sample, per cent)

\begin{tabular}{lcc}
\hline & $\mathbf{2 0 0 8}$ & $\mathbf{2 0 0 9}$ \\
\hline March & 3.4 & 18.3 \\
April & 33.1 & 35.5 \\
May & 56.7 & 19.7 \\
June & 6.8 & 8.9 \\
July & 0 & 9.4 \\
August & 0 & 8.1 \\
Total no. of observations & 6687 & 7199 \\
\hline
\end{tabular}

Appendix Table 12.A2 Occupational distribution of self-employed migrants by year (migrant sample)

\begin{tabular}{lccccc}
\hline & \multicolumn{2}{c}{2008} & \multicolumn{2}{c}{2009} & $\begin{array}{c}\text { Difference } \\
\text { in } \%\end{array}$ \\
\hline Semi-professional & Frequency & $\%$ & Frequency & $\%$ & 0.00 \\
Owners & 21 & 0.01 & 27 & 0.01 & -0.19 \\
Street vendors/garbage & 968 & 0.61 & 867 & 0.42 & 0.06 \\
collectors & 185 & 0.12 & 357 & 0.17 & \\
Shop assistants & 147 & 0.09 & 394 & 0.19 & 0.10 \\
Hospitality service workers & 29 & 0.02 & 104 & 0.05 & 0.03 \\
Domestic helpers & 4 & 0.00 & 4 & 0.00 & 0.00 \\
Hairdressers & 39 & 0.02 & 52 & 0.03 & 0.00 \\
Repair/removal/transport & 63 & 0.04 & 84 & 0.04 & 0.00 \\
workers & & & & & \\
Chefs/kitchen hands & 36 & 0.02 & 47 & 0.02 & 0.00 \\
Drivers & 30 & 0.02 & 14 & 0.01 & -0.01 \\
Other services labourers & 11 & 0.01 & 8 & 0.00 & 0.00 \\
Construction labourers & 19 & 0.01 & 38 & 0.02 & 0.01 \\
Other labourers & 38 & 0.02 & 74 & 0.04 & 0.01 \\
Total no. of observations & 1590 & & 2070 & & \\
\hline
\end{tabular}

\section{References}

Chen, X. 2009, 'Around 20 million rural migrants lost their jobs, need to confront these social problems', Caijing.com.cn, 2 February 2009, <http:// www.caijing.com.cn/2009-02-02/110051988.html>

Fallon, P. R. and Lucas, R. E. B. 2002, 'The impact of financial crises on labor market, household incomes and poverty: a review of evidence', The World Bank Research Observer, vol. 17, no. 1, p. 21. 
Huang, J., Zhi, H., Huang, Z., Rozelle, S. and Giles, J. 2010, Impact of the global financial crisis on off-farm employment and earnings in rural China, Unpublished manuscript.

Hugo, G. 2000, 'The impact of the crisis on internal population movement in Indonesia', Bulletin of Indonesian Economic Studies, vol. 36, no. 2, pp. 115-38.

Kong, T., Meng, X. and Zhang, D. 2009, 'Impact of economic slowdown on migrant workers', in R. Garnaut, L. Song and W. T. Woo (eds), China's New Place in a World in Crisis: Economic, geopolitical and environmental dimensions, ANU E Press and Brookings Institution Press, Canberra and Washington, DC, pp. 233-60.

Lewis, W. A. 1954, 'Economic development with unlimited supplies of labour', Manchester School, vol. 22, no. 2, pp. 1139-91.

Manning, C. 2000, 'Labour market adjustment to Indonesia's economic crisis: context, trends and implications', Bulletin of Indonesian Economic Studies, vol. 36, no. 1, pp. 105-36.

Ministry of Human Resources and Social Security (MoHRSS) 2009, The response of China's employment of rural migrants to the GFC, Series of reports on China's employment strategies against the global financial crisis, Unpublished manuscript.

Ministry of Human Resources and Social Security (MoHRSS) 2010, An investigation on employment demand of enterprises in Spring 2010 and employment situation of rural migrants in 2009, Unpublished manuscript.

National Bureau of Statistics (NBS) 2009, The total number of rural migrants (in China) was 225.42 million by the end of 2008, Press release, National Bureau of Statistics, Beijing, viewed 25 March 2009, <http://www.cpirc.org.cn/tjsj/ tjsj_cy_detail.asp?id=10471>

Ranis, G., and Fei, J.C.H. 1961. 'A theory of economic development', American Economic Review, Vol. 51 No. 4:533-65.

World Bank (2009) From poor areas to poor people: China's evolving poverty reduction agenda: An assessment of poverty and inequality in China World Bank, Washington D.C, Chunlai Chen. 